JOLANTA DOMINIKA ŻOŁNIERCZYK \& ZOFIA MARIA KILIAŃSKA

Department of Cytobiochemistry, University of Lódź, Pomorska 141/143, 90-236 Łódź, Poland, jolantazolnierczyk@gmail.com

\title{
MAIN PRO-APOPTOTIC MEMBER OF BCL-2 FAMILY PROTEINS - BAX
}

\begin{abstract}
Programmed cell death (apoptosis) plays a vital role in the regulation of cellular homeostasis. Because of apoptosis fundamental importance, this process is highly regulated. One important set of factors involved in apoptosis regulation is the Bcl-2 family proteins. Bcl-2 family members form a complex regulatory network that controls cell survival and death in response to different physiological and pathological signals. This family includes both pro- and anti-apoptotic members, and Bax protein (Mol wt $21 \mathrm{kDa}$ ) is a major pro-apoptotic factor with multifunctional activity. This review summarizes new data about the main representative of Bcl-2 family - Bax, its structure and mechanism(s) by which this protein modulates apoptosis.
\end{abstract}

Key words: apoptosis, Bcl-2 family, Bax, apoptosis mitochondrial pathway

\section{INTRODUCTION}

Apoptosis is a precisely controlled mode of eliminating injured, mutated or unwanted cells from the body or an organ of multicellular organism that, in contrast to necrosis, does not trigger the inflammation (HENGARTNER 2000; WYLLIE 2010). It is widely accepted that apoptosis may go through two major pathways (extrinsic and intrinsic), one of which involves mitochondria with proteins localized inside the intermembrane compartment of these organelles (KILIAŃSKA 2002). The mitochondrial (intrinsic) pathway of apoptosis is activated in response to several proapoptotic stimuli such as DNA damages, alterations in cytoskeleton stability 
(Rodolfo, Piacentini 2002; Ndozangue-Touriguine et al. 2008), reactive oxygen species (ROS), endoplasmic reticulum (ER) stress (MEIR et al. 2010), hypoxia (GREIJER, VAN DER WALL 2004), cytokine deprivation (SAVARAJ et al. 2010; WYLLIE 2010), oncogene overdrive (WYLLIE 2010) as well as a large number of anticancer drugs (ŻOŁNIERCZYK et al. 2009; RogALIŃSKA et al. 2010). All these death signals lead to permeabilization of outer mitochondrial membrane (OMM) and to the leakage of proapoptotic factors (procaspases, including procaspase-9, cytochrome c, Smac/DIABLO (Second mitochondria-derived activator of caspases/Direct IAP-binding protein with low $\mathrm{pI}$ ), apoptosis inducing factor - AIF, endonuclease G, Omi/HtrA2 (High temperature requirement protein A2) protease as well as some heat shock proteins - Hsp10 or Hsp 60) into the cytosol where they initiate caspase activation and DNA fragmentation (KRAJEWSKI et al. 1999; SHAN et al. 2003; LOWE et al. 2004; BEDNAREK, KILIAŃSKA 2005). It is thought that protein efflux out of mitochondria is irreversible step of apoptosis. Therefore, it must be accurately controlled (CHIPUK et al. 2006; CHIPUK, GREEN 2008). A key role in this regulation is attributed to $\mathrm{Bcl}-2$ (B-cell leukemia/lymphoma 2) family proteins many of which have become the objects of targeted therapy in oncology (BORNER 2003; WARR, SHORE 2008; WyLliE 2010). This review focuses on the current data concerning the structure and biological activity of the main pro-apoptotic member of Bcl-2 family proteins, Bax, and especially the mechanisms by which it evokes OMM permeabilization and apoptosis induction.

\section{BCL-2 FAMILY PROTEINS}

Up to now, over 30 proteins have been identified in higher eukaryotic cells that belong to Bcl-2 family (SKOMMER et al. 2007). They are all generally characterized by the presence of at least one highly conserved motif referred as Bcl2 homology domain $(\mathrm{BH})$ in their molecules. These domains, in number 1-4, take part in the mutual interactions between Bcl-2 family proteins as well as in the communication with other factors endowed with similar BH domain i.e. HAX-1 (Hematopoietic-specific protein 1-associated protein X-1) (YEDAVALLI et al. 2005; 
Hossini, EBERLE 2008). The Bcl-2 family comprises three subfamilies of proteins (Fig. 1):

- Bcl-2-like survival factors - multi-domain anti-apoptotic proteins i.e. Bcl-2, Bcl- $\mathrm{X}_{\mathrm{L}}$ (Bcl-2 related gene, long isoform), Bcl-w (Bcl-2 widely expressed), Mcl-1 (Myeloid cell leukemia-1), Bcl-B (Bcl-2 family protein resembling Boo) and A1/Bfl-1 (Ke et al. 2001; BorNER 2003; CORY et al. 2003; DroIn, GREEN 2004; REED 2008; SCHRÖDER 2008). These subfamily members typically possess $4 \mathrm{BH}$ domains in their structure and they are usually anchored to intracellular membranes of the cell.

- Bax-like death factors - multi-domain pro-apoptotic proteins e.g. Bax (Bcl-2 associated x protein), Bak (Bcl-2 antagonist/killer 1), Bok/Mtd (Bcl-2-related ovarian killer/Spanish: Matador - the killer), Bcl-X $\mathrm{X}_{\mathrm{S}}$. They have three (or 4 in case of Bok/Mtd) BH domains and play a role as effector molecules capable of directly inducing mitochondrial permeabilization and apoptosis (BORNER 2003).

- BH3-only death factors - single-domain pro-apoptotic proteins e.g. Bad (Bcl-2 antagonist of cell death is equivalent to $\mathrm{Bcl}-2$ associated death promoter), Bid (BH3-interacting domain death agonist), Bik (Bcl-2 interacting killer), Bim (Bcl2 interacting mediator of cell death), Bmf (Bcl-2 modifying factor), BNIP3 (Bcl2 and adenovirus E1B 19-kDa protein interacting protein 3), Bnip3L (Bnip3like), Hrk (Harakiri), Noxa/APR, Puma (p53-upregulated modulator of apoptosis) and Spike (Small protein with inherent killing effect). The members of this subfamily contain exclusively one domain - BH3; some of BH3-only proteins contain transmembrane domain, TM. They interact with Bax-like as well as Bcl-2-like proteins determining the fate of a cell (GUO et al. 2001; Moldoveanu et al. 2006; SKOMMer et al. 2007; Hossini, EBERLE 2008; REED 2008).

Recently, several other pro-apoptotic proteins have been discovered, however their classification turned out to be very difficult due to the presence of only two BH domains in their structure. For example, Bfk (Bcl-2 family kin) and Bcl-G proteins contain $\mathrm{BH} 2$ and $\mathrm{BH} 3$ while $\mathrm{Bcl}-\mathrm{X}_{\mathrm{S}}(\mathrm{Bcl}-2$ related gene, short isoform) and $\mathrm{Bcl}-\mathrm{X}_{\mathrm{AK}}(\mathrm{Bcl}-2$ related gene, alternative killer) are equipped with $\mathrm{BH} 3$ 
and $\mathrm{BH} 4$ or $\mathrm{BH} 2$ and $\mathrm{BH} 4$ domains, respectively; the latter is usually connected with anti-apoptotic potential of proteins (BORNER 2003; KARST, LI 2007; HosSINI, EBERLE 2008). Similarly, Bcl-rambo shares the structural homology with antiapoptotic factors of Bcl-2 family although its overexpression induces apoptosis (KATAOKA et al. 2001; HossinI, EBERLE 2008). Boo/Diva (Death inducer binding to vBcl-2 and Apaf-1) protein that comprises $4 \mathrm{BH}$ domains may in turn act as proapoptotic or pro-survival molecule depending on the cellular context (LEE et al. 2001).

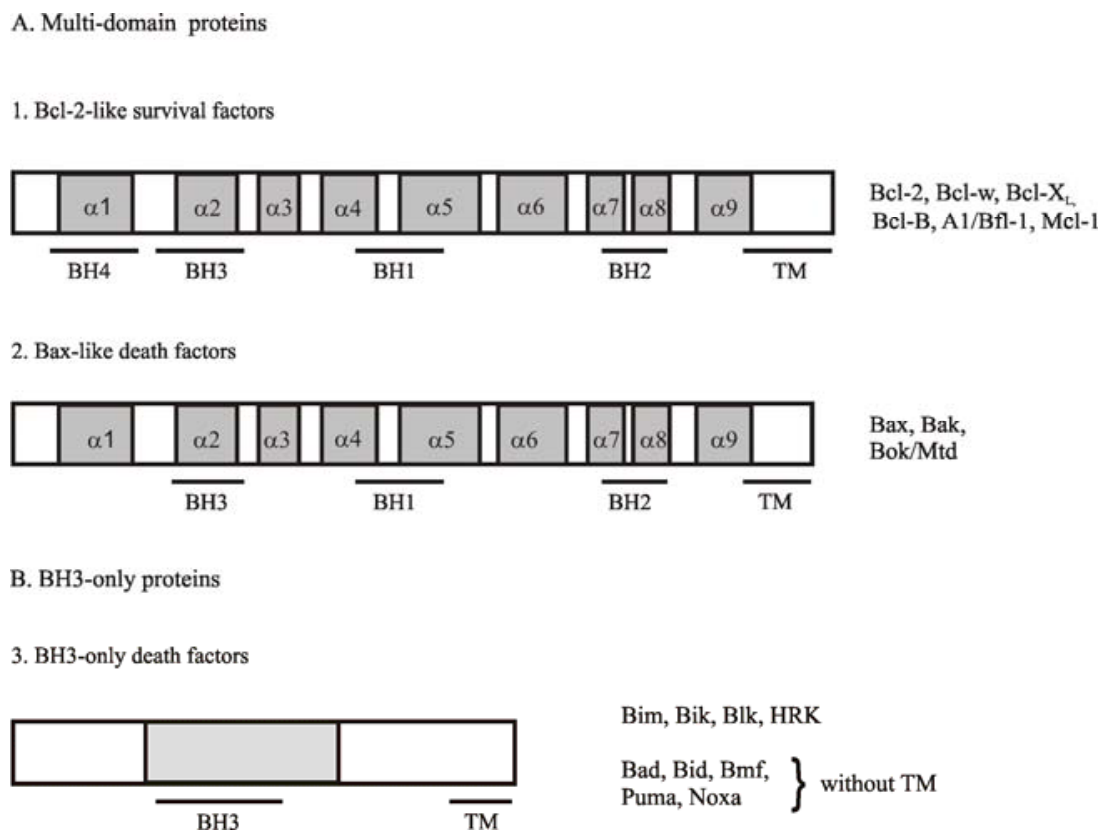

Fig. 1. Domain structure of Bcl-2 family proteins (based on: CHIPUK et al. 2006; CHIPUK et al. 2008; BORNER 2003). The Bcl-2 family of proteins (multi-domain - A; BH3-only - B) is divided into 3 functional subfamilies $(1,2$, and 3) based on their composition of BH (1-4) domains. For more details see text. $\alpha 1-9-\alpha$-helices; BH Bcl-2 homology domain; TM - transmembrane domain. The BH3 domain in the pro-apoptotic proteins is a ligand for the hydrophobic pocket formed by the $\mathrm{BH} 1$ BH3 domains of the anti-apoptotic members of Bcl-2 family.

The classification of Bcl-2 family proteins based on their role in apoptosis seems to be rather conventional since the phenotype of many pro- or anti-apoptotic 
proteins can be changed into the opposite one under some special conditions (LIN et al. 2004; HANSON et al. 2008). For example, Bcl- $\mathrm{X}_{\mathrm{L}}$ protein, known as antiapoptotic factor, may interact with mitochondria and induce OMM permeabilization after the binding phosphorylated K-Ras (phosphorylation on $\mathrm{Ser}^{181}$ ). Likewise, interaction of Bcl-2 protein with orphan receptor - Nur 77 (Nuclear receptor 77) converts the anti-apoptotic potential of Bcl-2 to pro-apoptotic (KOLLURI et al. 2008). It was demonstrated that Nur 77 also affected other generally anti-apoptotic proteins, such as Bcl-B, A1/Bfl-1, leading to reversion of their phenotype (LUCIANO et al. 2007).

\subsection{Structure of Bcl-2 family proteins}

Examination of the solution structure of Bcl-2 family proteins revealed some structural resemblances between pro- and anti-apoptotic molecules. These proteins adopt donut-shaped structure with two central, hydrophobic $\alpha$-helices surrounded with 6-7 amphipathic $\alpha$-helical regions. Additionally, they contain a long (60 aa), unstructured loop between the first and the second helical region of proteins (Petros et al. 2004; SKOMMER et al. 2007; BORNER 2003).

$\mathrm{BH} 1, \mathrm{BH} 2$, and $\mathrm{BH} 3$ domains play an important role in the interactions of anti-apoptotic proteins with their pro-apoptotic opponents (PETROs et al. 2004; HOSSINI, EBERLE 2008)]. In pro-survival as well as in inactive pro-apoptotic proteins above domains form together a hydrophobic pocket which binds $\mathrm{BH} 3$ motif of proapoptotic molecule by electric and hydrophobic interactions (BORNER 2003; PETROS et al. 2004; HOSSINI, EBERLE 2008). Evolutionary conserved amino acid residues Gly ${ }^{145}$ and $\mathrm{Arg}^{146}$ localized in $\mathrm{BH} 1$ as well as $\operatorname{Trp}^{188}$ in $\mathrm{BH} 2$ domain of antiapoptotic proteins play a key role in the communication between the receptor pocket and $\mathrm{BH} 3$ domain of pro-death factor. It was indicated that the substitution of Gly145Ala/Glu and Trp188Ala prevented the heterodimerization of Bcl-2 family proteins, suggesting that these residues take part in the binding of hydrophobic clef to BH3 domain (GURUDUTTA et al. 2005).

The in vitro tests revealed that both Bax and Bcl-2 proteins were able to form channels permeable for chloride or potassium ions, respectively in the membranes 
(Borner 2003; Petros et al. 2004). The process of pore forming required hydrophobic $\alpha-5$ and $\alpha-6$ helices overlapping the BH1 domain and the stretch between $\mathrm{BH} 1$ and $\mathrm{BH} 2$ regions. Both of them bear a resemblance to toxins produced by some bacterial strains (i.e. Escherichia coli or Corynebacterium diphtheriae) against others. It is thought that the selectivity of Bcl-2 family protein-forming channel is determined by amino acid sequence and electric charge of molecule(s) engaged in its assembly. Moreover, the chemical composition of the membrane surrounding the protein is not insignificant for its poration activity (CHRISTENSON et al. 2008). It has been shown that negatively charged phospholipid - cardiolipin supports the pore-forming activity of Bax whereas cholesterol-rich bilayers inhibit Bax integration into the membranes (CHRISTENSON et al. 2008).

BH3 domain is composed of 9-16 amino acid residues highly conserved among all Bcl-2 family proteins. It fulfils the role of ligand binding region which is necessary for both hetero- and homo-dimerization and apoptosis triggering (FREY et al. 2008). The BH3 domain of anti-apoptotic proteins is an integral part of hydrophobic cleft built with $\mathrm{BH} 1, \mathrm{BH} 2$ and $\mathrm{BH} 3$ in contrast to the $\mathrm{BH} 3$ domains of pro-apoptotic factors of this family which are hidden inside the molecules of inactive proteins or are exposed to the outside of the molecules when they are active (Borner 2003; Petros et al. 2004). Unbound BH3 domain of free pro-apoptotic proteins indicates unorganized structure while after their dimerization with prosurvival partners it forms amphiphatic helix penetrating the hydrophobic pocket (BORNER 2003). It is worth mentioning that the substitution of $\mathrm{Asp}^{160}$ in $\mathrm{BH} 3$ domain of Bad with Arg that facilitates the adoption of $\alpha$-helical structure widely increased the affinity of BH3 peptide to Bcl-X $\mathrm{X}_{\mathrm{L}}$ protein (PETROS et al. 2004).

In addition, the amino acid sequence of Bcl-2 family proteins plays an important role for this interaction. It has been reported that conserved residues - Leu and Asp occupy the position 1 and 6 of BH3 domain in all Bcl-2 family members, whereas Ala or any hydrophobic amino acid (usually Ile) is situated at position 4 of $\mathrm{BH} 3$ domain in anti- or pro-apoptotic proteins, respectively.

$\mathrm{BH} 4$ domain is localized in amino terminal region of anti-apoptotic Bcl-2 family members as well as some pro-apoptotic proteins $\left(\mathrm{Bcl}-\mathrm{x}_{\mathrm{s}}\right.$, Bcl-rambo, 
Bok/Mtd, Boo/Diva) (Hossini, EBERLE 2008). For a long time, it was thought that BH4 domain was responsible for apoptosis inhibiting activity of pro-survival molecules (Hossini, EBERLE 2008). However, some anti-apoptotic proteins, e.g. Mcl-1, do not possess the above conserved region, but they all include a helical region $-\alpha 1$. In most of anti-apoptotic proteins this motif is enclosed in the BH4 domain. Currently, it seems that just this helical structure controls pro-survival function of Bcl-2 inhibitors regardless of its amino acid sequence. Similar $\alpha$-helical region was found in Bax molecule in which it negatively regulates pro-apoptotic function of this protein (CARTRON et al. 2004).

Some anti-apoptotic Bcl-2 family members contain a 60-aa regulatory loop between $\alpha-1$ and $\alpha-2$ helices that seems to work as a region of autoinhibition (Lin 2004, Petros et al. 2004). Chemical modifications (such as phosphorylation) within a given region result in abolishing the pro-survival potential of anti-apoptotic proteins and conversion of their phenotype.

Most of Bcl-2 family representatives contain a C-terminal 15-20-aa hydrophobic sequence - transmembrane (TM) domain - neighboring positivelycharged amino acid residues of Lys or Arg, that enables them to attach to the membranes of mitochondria, endoplasmic reticulum or cell nuclei (PETROs et al. 2004; SCHINZEL et al. 2004a). Some of the proteins anchor to membranes immediately after their synthesis while others possess a transmembrane domain hidden inside their molecule and require to pass some conformational changes to expose TM on the surface (BORNER 2003; SCHINZEL et al. 2004a).

\section{BAX PROTEIN - A KEY EFFECTOR IN MITOCHONDRIAL PATHWAY OF APOPTOSIS}

Human Bax gene is located on long arm of chromosome 19 within the region q13.3-q13.4 (APTE et al. 1995). This gene is about 4500 bp long and contains six exons. Alternative splicing of its primary transcript produces several isoforms of $\operatorname{Bax}(\alpha, \beta, \gamma, \delta, \omega, \sigma$ and $\Psi)$ (CARTRON et al. 2002; Droin, GreEN 2004). In ischemic rat brain a novel splice variant of Bax, Bax $\kappa$, was identified (JIN et al. 2001). Main variant, firstly isolated - Bax $\alpha$ is encoded by all exons and has a molecular weight 
of $21 \mathrm{kDa}$ (192 aa). Its name - Bax (Bcl-2 associated x protein) is derived from its ability to neutralize and block the function of the main anti-apoptotic protein - Bcl-2 (BORNER 2003). Function of the rest of Bax variants still remains unknown (DroIN, GREEN 2004). The promoter of Bax has two canonical E-box motifs that bind cMyc/Max (Myc associated factor $X$ ) heterodimers. Moreover, Bax is under the control of P53 transcription factor and is involved in P53-mediated apoptosis (CARTROn et al. 2002).

Bax protein - an effectory promoter of apoptosis is constitutively expressed in the cells. In vital cells the described polypeptide is identified only as an inactive monomer or as the molecule bound to anti-apoptotic partner. Apoptosis-inhibitory proteins have a potential to neutralize the function of pro-death factors (CHIPUK et al. 2006; ChIPUK, GreEN 2008). It is accepted that in vital cells Bax is mainly localized in the cytosol, although it can be loosely attached to intracellular membranes (SCHINZEL et al. 2004b; SCHLESINGER, SAITO 2006). After activation in response to pro-death signals, Bax undergoes some conformational changes thereby incorporating the mitochondrial membranes persistently, forming pores and inducing OMM permeabilization (CHIPUK et al. 2006; CHIPUK, GREEN 2008). In active state this protein indicates diminished sensitivity to alkaline treatment, trypsin digestion as well as decreased susceptibility to proteolysis of $\alpha 5$ and $\alpha 6$ helices (BORNER 2003). In this state a significant increase of N-terminal region of Bax immunoreactivity (6A7 epitope between 13 and 19 amino acids) was demonstrated. However, this feature is thought to be reversible and independent of pro-survival Bcl-2 proteins (BORNER 2003; SHARPE et al. 2004). It would seem that the 6A7 epitope exposition on the surface of Bax appears at very early stage of its conformational changes and it precedes protein oligomerization. Therefore, this immunoreactivity elevation can not be strictly identified with Bax activation and apoptosis induction (SHARPE et al. 2004). In addition, it is believed that Bax translocation and oligomerization are not enough to induce permeabilization of OMM, although they both are required (SKOMMER et al. 2007).

Bax protein shares a strong similarity of its tertiary structure with antiapoptotic members of Bcl-2 family, such as Bcl-2 and Bcl-X $\mathrm{L}_{\mathrm{L}}$ (SUZUKI et al. 2000; 
BORNER 2003; Petros et al. 2004). Above polypeptide contains $9 \alpha$-helices. The seven of them surround two centrally-localized hydrophobic $\alpha$-helical structures. The helix $\alpha 5$ is positioned the most internally in the molecule. Between helices $\alpha-1$ and $\alpha-2$ a long flexible loop region can be observed. $\mathrm{BH} 1, \mathrm{BH} 2$ and $\mathrm{BH} 3$ domains of the described protein, embraced with $\alpha-2, \alpha-3$ and $\alpha-4$ helices, lay in the same orientation as the domains of $\mathrm{Bcl}-\mathrm{X}_{\mathrm{L}}$. In living cells they form hydrophobic cleft in analogous manner as anti-apoptotic proteins. It prevents from Bax dimerization under normal conditions (DROIN, GREEN 2004). In contradiction with Bcl- $\mathrm{X}_{\mathrm{L}}$ or Bcl2 proteins, $\mathrm{BH} 3$ domain of Bax does not go so deep into the hydrophobic pocket of a protein. Additionally Bax, similarly as anti-apoptotic factors, possesses in Cterminus a transmembrane region responsible for directing of the molecule to the mitochondrial membrane (Fig. 1) (SUZUKI et al. 2000; SCHINZEL et al. 2004b). However, TM region of Bax, unlike of $\mathrm{Bcl}-2$ or $\mathrm{Bcl}-\mathrm{X}_{\mathrm{L}}$, is not exposed to the cytosol. Instead of that, it moves back towards the pocket and binds to it as Bak or Bad proteins bind the hydrophobic pocket of Bcl-X $\mathrm{L}_{\mathrm{L}}$ (SUZUKI et al. 2000; BORNER 2003; Petros et al. 2004). It has been revealed that a hydrogen bound formed by hydroxyl group of $\mathrm{Ser}^{184}$ side chain and carboxyl group of $\mathrm{Asp}^{98}$ is directly involved in the interaction between $\mathrm{C}$-terminus of $\mathrm{Bax}$ and $\alpha 4$ region of its hydrophobic pocket (SUZUKI et al. 2000). It is also possible that C-terminus of Bax protein takes part in pocket stabilization and plays a role in the regulation of its translocation and oligomerization (SUZUKI et al. 2000; CARTRON et al. 2004). If the C-terminus of Bax is folded the pocket remains in a stable conformation. While the region is removed out of the hydrophobic cleft, the pocket collapses and the protein structure changes leading to protein dimerization and to its interaction with mitochondrial membrane. It is suggested that a removal of $\alpha-9$ helical region (TM) is initiated by posttranslational modification of Bax (i.e. phosphorylation of Ser and Thr residues present in that region in large numbers) or some currently unknown factor, from behind of BH3-only subfamily, that competes with Bax for binding of its hydrophobic cleft. Interestingly, Pro ${ }^{168}$ can be a direct or indirect linker between Nand C-termini of Bax protein displaying a function in the stabilization of its structure (SCHINZEL et al. 2004b). Destruction of this interaction under apoptotic signal(s) 
results in the exposition of TM domain and translocation of pro-apoptotic protein to the mitochondria. It is possible that Pro ${ }^{168}$ is a target for Pin 1 isomerase activity (peptidylprolyl cis/trans isomerase, NIMA-interacting 1) or a substrate for hydroxylation reactions.

BORNER suggested sequential events that may occur in Bax-like proteins during the apoptosis induction (2003). According to this model Bax-like proteins are present in living cells in the cytosol in the form of monomers or remain loosely attached to OMM. This kind of contact does not lead to remodeling of Bax hydrophobic cleft which is stabilized by interactions with membrane phospholipids or some unidentified inhibitory factors. In the case of Bax the C-terminus of the protein needs to be released from the binding with its hydrophobic pocket. In contrast, Bak doesn't require any extra signals because of its anchoring region that is always exposed outside the molecule. An alternative scenario assumes that the pushing aside $\alpha 9$ helix of the molecule evokes immediate changes in the protein structure: disintegration of hydrophobic cleft and exposition of BH3 domain. However, even then the incorporation of Bax to the membranes cannot be achieved because of the Bcl-2 anti-apoptotic proteins inhibiting BH3 domain of this pro-death molecule. Only in the presence of activated BH3-only proteins there occurs the release of Bax from the interaction with $\mathrm{Bcl}-2$ or $\mathrm{Bcl}-\mathrm{X}_{\mathrm{L}}$. As a result of the liberation, $\operatorname{Bax} \alpha 5 / \alpha 6$ helices can stably incorporate into the mitochondrial membranes. It is also possible that Bax may be auto-activated or cross-activated with already active Bax-like molecules without the participation of BH3-only proteins. The next step of OMM permeabilization is the oligomerization of effector proteins (Bax, Bak, Bok) and pore forming. It is conceivable that this stage can also be stopped by Bcl-2-like proteins if they are overexpressed in the cells (BORNER 2003). Therefore, apoptosis-mediating signals must generate multidirectional response to abrogate the multistage inhibition of anti-apoptotic proteins.

It was thought for a long time that $\alpha 9$ helix of Bax was only one region directing the molecule to the mitochondria. However, in 2004 CARTRON et al. suggested the presence of additional mitochondrial targeting sequence in $\alpha 1$ helix of that protein and proposed an alternative to Borner's manner of Bax activation and 
translocation. In viable cells, $\alpha 1$ helix of inactive Bax protein is situated close to $\alpha 2$ (BH3 domain), $\alpha 5$ and $\alpha 6$ regions and guards against their mitochondrial insertion (GRIFFITHS et al. 2001, MoldoveANu et al. 2006). According to the cited authors (CARTRON et al. 2004) the negative regulation of above helix is abrogated by its interaction with $\mathrm{BH} 3$ domain of the so-called direct activators from $\mathrm{BH} 3$-only proteins, e.g. Bid, Bim or Puma. This interaction leads to the opening of Bax molecule and to the exposure of $\alpha 1$ on the surface of pro-apoptotic protein. It has been established that $\mathrm{Asp}^{33}$ of Bax and $\mathrm{Gly}^{94}{ }^{3} \mathrm{Met}^{97}, \mathrm{Arg}^{84}$ of $\mathrm{BH} 3$-only protein play a key role in this binding. The hypothesis of CARTRON et al. (2004) arouses many controversies (SCHINZEL et al. 2004b, MING et al. 2006). It has been indicated that mitochondrial localization sequence is preceded by ART (apoptosis-regulating targeting domain) inhibitory domain (SCHINZEL et al. 2004b). Only if it was removed from the protein, the sequence would be uncovered. Thus, N-terminus of protein performs a role presumably only in inhibition of Bax activity. Indeed, its elimination from the molecule results in producing more potent pro-apoptotic protein - p18 Bax (CAO et al. 2003). Interestly, during apoptosis N-terminus of Bax may be cleaved by calpains (GAO, Dou 2000). Furthermore, transfection of Bax/p18 fragment into cancer cells targeted this cleaved protein segment to mitochondria, which was accompanied by release of cytochrome $\mathrm{c}$.

It has been demonstrated very recently (GEORGE et al. 2010) that Bax contains two functional mitochondrial targeting sequence that may act independently in mitochondrial translocation of Bax. They are located in helices $\alpha 6$ and $\alpha 9$ and uncovering of one of them after conformational changes of Bax, directs the molecule to mitochondrial membrane. It has been revealed that only combined mutations in both of these regions preclude its mitochondrial translocation in HeLa cell line.

\section{MECHANISMS OF BAX-INDUCED MITOCHONDRIAL OUTER MEMBRANE PERMEABILIZATION}

Bcl-2 family proteins regulate apoptosis via their influence on mitochondrial membrane permeability and efflux of pro-apoptotic factors from intermembrane 
space of mitochondria, releasing $\mathrm{Ca}^{2+}$ ions from endoplasmic reticulum as well as on redox state in cell resulting from a translocation of cytochrome $\mathrm{c}$ to the cytosol, disruption of respiratory chain in mitochondria and production of reactive oxygen species (ROS) (BRECKENRIDGE et al. 2003; REED 2008; HANSON et al. 2008; HETZ, GLIMCHER 2008).

At present, it is accepted that Bax-mediated permeabilization may run through one of the following models. The most common mode of Bax action is that after homo- or heterodimerization with other pro-apoptotic Bcl-2 family molecules, Bax-like proteins form in outer mitochondrial membrane channels big enough to let pass cytochrome $\mathrm{c}$ and/or other pro-apoptotic factors, including procaspase- 9 which together with cytochrome $\mathrm{c}$ forms apoptosome and initiates apoptosis (KRAJEWSKI et al. 1999; SCHLESINGer, SAito 2006; Kumarswamy, ChANDNA 2009).

According to the next hypothesis, supported by experiments with liposome, Bcl-2 family proteins interact with channels that already exist in the membrane, e.g. with voltage-dependent anion channel (VDAC), and create structure permeable for molecules of the size of cytochrome $\mathrm{c}$ and even bigger (KUMARSWAMY, CHANDNA 2009).

Importantly, Bax may cooperate with proteolytically truncated $\mathrm{BH} 3$-only member Bid (tBid) and $\mathrm{Ca}^{2+}$ in permeabilizing the outer mitochondrial membrane and releasing mitochondrial apoptogenic factors (LUO et al. 1998; WEI et al. 2000; Desagher et al. 1999; BedNAREK, KiLIAŃSKA 2005; BRUSTOVETSKY et al. 2010). Recent data have indicated that Bax and tBid together may induce the formation of a large lipid pore in mitochondrial membrane (TERRONES et al. 2004). It has been revealed that both of these proteins destabilize the structure of lipid bilayer and provoke pore formation. tBid protein facilitates lipid pore forming through its CBD domain (cardiolipin-binding domain) that directs pro-apoptotic proteins to cardiolipin-rich membranes (TERRONES et al. 2004).

Both, Bcl-2 and Bax proteins seem to be also involved in the regulation of $\mathrm{Ca}^{2+}$ release from endoplasmic reticulum (ER). During ER stress followed by accumulation of improperly folded proteins in the ER, overexpression of Bik protein induces Bax/Bak heterodimerization and leads to $\mathrm{Ca}^{2+}$ efflux from ER. Increase of 
the level of $\mathrm{Ca}^{2+}$ in the cytosol may stabilize open conformation mitochondrial megachannel - a large structure embracing both of mitochondrial membranes which, among others, can participate in cytochrome c releasing (CHIPUK et al. 2006).

\section{REGULATORS OF BAX ACTIVITY}

\subsection{Activators of Bax protein}

The main regulators of pro-apoptotic activity of Bax-like proteins are BH3only members of Bcl-2 family. They may be divided into two subgroups depending on the way how they reveal pro-apoptotic potential of the so-called effectors (CHIPUK et al. 2006; LeBER et al. 2007; SKOMMER et al. 2007):

- Direct activators (Bid-like proteins) e.g. Bid or Bim - proteins that transiently bind to Bax-like proteins and trigger their activation according to 'hit and run' model. They can also neutralize anti-apoptotic members of Bcl-2 family molecules.

- Derepressors or sensitizers (Bad-like proteins) e.g. Bad, Bik, Bmf, Noxa, Puma - proteins that do not exhibit a potential to activate Bax-like proteins directly but are able to release effectors from interaction with anti-apoptotic molecules.

The best known and the first described example of Bcl-2 family effector activation was tBid-dependent rearrangement of Bax molecule (ZAMZAMI et al. 2000). It has been established that the interaction of Bax with tBid induces conformational change in pro-apoptotic effectory molecule (exposure of 6A7 epitope on the molecule) resulting in protein translocation, incorporation to mitochondrial membranes and eventually their permeabilization.

Importantly, Bax can be also directly activated by factors that do not belong to Bcl-2 family. It has been demonstrated that cytoplasmic form of tumor suppressor protein - P53 induces Bax oligomerization and permeabilization of lipid vesicles at the level comparable to that obtainable with tBid (CHIPUK, GREEN 2004). It appears that a proline-rich region of P53 located between 62. and 91. amino acid residues is required for direct activating of Bax molecule. The deletion of this segment fails to permeabilize the membrane and arrests cytochrome c and other pro-apoptotic molecules inside the mitochondria. Additionally, P53 may also act as a derepressor - 
a molecule that binds to anti-apoptotic protein $\left(\mathrm{Bcl}-\mathrm{X}_{\mathrm{L}}\right)$ and releases of Bax from the interaction with its inhibitor.

Recently, several reports have revealed that calpain-activated protein product of Atg5 (autophagy-related gen 5) gene exhibits potential to activate the members of Bax-like family (Codogno, MeiJer 2006, Yousefi et al. 2006). Its $24 \mathrm{kDa}$ $\mathrm{N}$-terminal region, freed after the calpain-mediated cleavage, translocates from the cytosol into the mitochondrial membrane, thereby inducing apoptosis. Thus, Atg5 plays a role of autophagy-apoptosis switch. However, the mechanism of Atgmediated Bax activation remains unclear.

Furthermore, CUDDEBACK et al. (2001) have reported the Bax-activating action of Bif-1/endophilin B1 (Bax-interacting factor 1) in murine pre-B hematopoietic FL5.12 cell line following IL-3 withdrawal. It has been also revealed that loss of Bif-1 protein inhibits Bax/Bak-mediated apoptosis in HeLa cells treated with siRNA, as well as in Bif-1-knockout mouse embryonic fibroblasts (MEFs), obtained from mouse ES cells through homologous recombination (TAKAHASHI et al. 2005). It seems that after apoptosis induction Bif-1 undergoes some posttranslational modification(s) enabling its binding to Bax protein. This association triggers conformational rearrangement in Bcl-2 family molecule and this incident is accompanied by its activation and incorporation into the mitochondrial membrane. Once Bax is activated, complex branches out (CUDDEBACK et al. 2001, TAKAHASHI et al. 2005). Moreover, it is thought that a failure of Bif-1 may contribute to the development of tumors under in vitro as well as under in vivo conditions.

In addition, Bax can also interact with P53-dependent protein - ASC (Apoptosis associated speck-like protein containing a caspase recruitment domain) which moves to mitochondria after apoptosis induction and, in this way, facilitates Bax relocation (LEBER et al. 2007). Similarly, it has been indicated that histone H1.2 trafficking is a part of events leading to Bcl-2 family pro-apoptotic proteins activation, mitochondrial membrane permeabilization and apoptosis induction upon cell death stimulation (YAN, SHI 2003). It is unclear, however, how exactly H1.2 histone acts to provoke Bax/Bak oligomerization after its release to the cytosol. 
It is worth mentioning that under special environmental circumstances, Bax and Bak molecules, can be activated in vitro without contribution of any additional proteins e.g. in response to nonionic detergents, $\mathrm{pH}$ increase or growth of temperature (BORNER 2003). Nevertheless, it is not known if this kind of Bax activation occurs under physiological conditions.

\subsection{Inhibitors of Bax protein}

Among Bax regulators, with the exception of Bcl-2-like proteins that neutralize pro-apoptotic function of Bax, Ku70 protein - a component of DNA-PK (DNA-dependent protein kinase), 14-3-3 protein, and some Hsp proteins (Heat shock proteins) ( $\alpha \mathrm{A}$ and $\alpha \mathrm{B}$-crystalins, Hsp70/dj1 and Hsp70/dj2 complexes) are found (Lucken-Ardjomande, Martinou 2005; Gotoh et al. 2004; Sharpe et al. 2004; SCHINZEL et al. 2004a). Anti-apoptotic activities of the above factors are probably associated with a sequestering of inactive Bax molecule in the cytosol. It has been revealed that the proteins abrogate apoptosis induced by several agents e.g., UV irradiation or staurosporine treatment, while their removal from the cells enhances cell susceptibility towards apoptosis.

Additionally, ASO (antisense oligonucleotides) strategy showed antiapoptotic potential of ARC protein (Activity-regulated cytoskeleton-associated protein), a factor, that is highly expressed in cardiac and skeletal muscle cells (LUCKEN-ARDJOMANDE, MARTINOU 2005). It was shown that the silencing of ARC expression contributed to conformational changes in the pro-apoptotic molecule Bax and mediated apoptosis. Bax activation and translocation can be brought to a halt by a new endogenous peptide - humanin, too (ZHAI et al. 2005). It was indicated that this 24-aa peptide is able to bind both with Bax and its direct activator - Bid (and tBid) and to inhibit tBid-induced Bax oligomerization.

It has been also suggested that Bax mediated apoptosis can be abolished by hexokinase-mitochondria interaction in a process regulated by Akt/PKB kinase activity (MAJEWSKI et al. 2004).

In 1998, XU and REED reported about the new anti-apoptotic protein, BI-1 (Bax inhibitor 1), discovered by functional screening in yeast. Above inhibitor is 
highly conserved in animals and plants (XU, REED 1998; HÜCKELHOVEN 2004). It has been well documented that BI-1 protein abrogates apoptosis followed by a large number of apoptotic stimuli, e.g. Bax overexpression, growth factor and cytokine deprivation, drug treatment (etoposide, staurosporine), bacterial pathogens (e.g. Chlamydia psittacci) in various cell lines (HüCKELHOVEN 2004). This protein neutralizes pro-apoptotic function of Bax. However, the mechanism of BI-1 action does not seem to be related to its physical interaction with Bax molecule. These two proteins do not appear to associate with themselves.

The main negative regulators of pro-apoptotic function of Bax are Bcl-2 family proteins. Bax can heterodimerize with $\mathrm{Bcl}-2, \mathrm{Bcl}-\mathrm{X}_{\mathrm{L}}, \mathrm{Bcl}-\mathrm{w}$ and, perhaps, with Mcl-1 proteins and these interactions prevent apoptosis in live cells (DROIN, GREEN 2004; EWINGS et al. 2007). After apoptosis induction, the release of Bax from the complexes with proteins that counteract its function takes place due to the fact that BH3-only proteins indicate approximately 100 times stronger affinity for anti-apoptotic Bcl-2-like members than their affinity for Bax (BORNER 2003). Free Bax molecules multimerize and/or interact with the components which already exist in the mitochondrial membranes forming a large channel permeable for cytochrome c and other pro-death factors. Thus, the cell fate depends essentially on the equilibrium between pro-survival and pro-apoptotic proteins. Indeed, it is well known that disruption of the balance between Bcl-2 family partners in the cells entails serious consequences manifested in the disorder of life-or-death decision and on the one hand, cell accumulation, or on the other hand, excessive cell elimination. Defective apoptosis causes a large number of diseases, including cancers, autoimmune syndromes, neurodegenerative disorders, diabetes, immunodeficiency syndromes, infertility (KILIAŃSKA 2002; PEREZ et al. 1997; BORNER 2003; HAYASHI, FAustman 2003; Moldoveanu et al. 2006; Frey et al. 2008).

\section{BCL-2 FAMILY PROTEINS - NEW TARGET FOR THE THERAPY OF DISORDERS WITH DEFECTIVE APOPTOSIS}

In viable cells pro-apoptotic proteins co-exist in dynamic balance with antiapoptotic counterparts from Bcl-2 family (DAY et al. 2008). It means that decreased 
expression of one of them leads to the reduction in the level of the other one. For example, in viable cells of HEK-293 cell line pro-apoptotic Bak is kept in check by pro-survival Mcl-1 protein, whereas a proper number of B lymphocytes in the body is strictly regulated by Noxa/Mcl-1 ratio in the cells. Admittedly, Bax requires some additional signals for its activation, but after apoptotic stimulation cell fate depends to a high degree on the equilibrium between Bax and its main inhibitor - Bcl-2 (OlTVAI, KORSMEYER 1993). The overexpression of anti-apoptotic protein results in cell accumulation and may conduce to survival of transformed cells (CORY et al. 2003). Bcl-2 over-expression has been indicated in leukemias, lymphomas and a large number of human solid tumors and its high level is often associated with unfavorable prognosis (CASTLE et al. 1993; CORNBLAU et al. 1999; DroIN, GREEN 2004). Correspondingly, Bax $\alpha$ gene is mutated in many cancers (e.g. derived from colorectum, stomach, endometrium cells) and its expression level influences on the effectiveness of apoptosis induction (BARGOU et al. 1995, WAGENER et al. 1996; RAMPINO et al. 1997; OUYANG et al. 1998; REED 1999; FERREIRA et al. 2002). Therefore, Bax/Bcl-2 ratio may reflect susceptibility of neoplastic cells to spontaneous as well as drug-induced apoptosis. For instance, the cellular level of Bax and Bcl-2 proteins in prostate cancer cells is a predictive factor forecasting the result of the therapy based on androgen deprivation and radiation (KHOR et al. 2007). It has been also shown that Bax/Bcl-2 rate in chronic lymphocytic leukemia (CLL) inversely correlates with resistance of leukemic cells to cytotoxic drug chlorambucil in vitro as well as with clinical responsiveness (PEPPER et al. 1997). Above parameter mirrors the potential of the examined cells to apoptosis induction and its analysis may serve in vitro as potential tool for evaluating whether neoplastic cells are drug resistant or not (KOBYLINSKA et al. 2006).

Owing to the key role of Bcl-2 family proteins in apoptosis regulation they are an attractive target for modern anti-cancer therapy. There are many therapeutical approaches leading to modification of cellular balance between pro- and antiapoptotic Bcl-2 family molecules. Most of them are targeted to pro-survival proteins and are based on antisense oligonucleotides (JANSEN et al. 1998; KONOPLEVA et al. 2000; FERREIRA et al. 2002). However, the number of trials aiming at inducing Bax 
gene in tumor cells is growing all the time (WAGENER et al. 1996; LI et al. 2001; PIROCANAC et al. 2002; FALKE et al. 2003). As the introduction of a vector expressing Bax gene into cells involves a lot of difficulties associated with putative toxic effect of its protein product on normal cells, it is a great challenge for scientists to cause a cancer cell-directed expression of this gene (SEO et al. 2009).

A new engineered artificial transcription factor, 5ZFAV, seems to be a solution to this problem (FALKE et al. 2003). It has been revealed that 5ZFAV, containing zinc fingers from mouse Zif268 and transactivation domain from herpes simplex virus protein, VP16, selectively induces the expression of endogenous Bax and efficiently turns apoptosis on in P53-deficient sarcoma osteogenic Saos-2 cells. Interestingly, the impact of the novel molecule on P53 positive osteosarcoma cell line - U-2 OS appears to be much less potent giving the chance for selective proapoptotic activity against P53-mutated tumor cells.

The Tet-On inducible system, containing reverse tetracycline transactivator (rtTA) and inducing transcription after the binding with tetracycline and its derivatives, seems to be very helpful in controlling Bax gene expression (WAGENER et al. 1996, SEO et al. 2009). It has been reported that the stable transfectants obtained from DLD-1 colon cancer cells transfected with above system ( $p T E T-O n$ and p-TRE Bax plasmids) and selected in the medium with geneticin, occur to be more sensitive to various drug-induced apoptosis than the cells without introduced Bax gene (KoBAYASHI et al. 2000).

On the other hand, it has been discovered that bax inactivation in oocytes of mice undergoing treatment with doxorubicine reduced their sensitivity to apoptosis and increased their viability (PEREz et al. 1997). Since it is well known that development of infertility in anticancer drugs-treated women is one of the most common side effect of chemotherapy, the inhibition of Bax gene in germinal cells during the chemotherapy of cancer could be interesting strategy of infertility preservation (PEREZ et al. 1997).

In conclusion, it seems that overexpression of Bax alone in cancer cells does not induce apoptosis but enhances its induction following anticancer treatment. A combination of conventional chemotherapy with gene therapy may be a new, very 
potent strategy in cancer treatment. It is conceivable that the better understanding of apoptosis regulation may help to overcome apoptosis deficiency (typical in many cancers) and therapy resistance.

\section{Acknowledgements}

Preparation of this article was supported by grant 505/0375 from the University of Łódź.

\section{REFERENCES}

APte, S.S., MAtTei, M.G., Olsen, B.R. 1995. Mapping of the human bax gene to chromosome 19q13.3-13.4 and isolation of a novel alternatively spliced transcript Bax delta. Genomics 26: 592-594.

Bargou, R.C., Bommert, K., Weinmann, P., Daniel, P.T., Wagener, C., MAPARA, M.Y., DÖRKEN, B. 1995. Expression of the bcl-2 gene family in normal and malignant breast tissue: low bax-alpha expression in tumor cells correlates with resistance towards apoptosis. Eur. J. Immunol. 25: 770-775.

BEDNAREK, J., KiLIAŃSKA, Z.M. 2005. Białka przestrzeni międzybłonowej mitochondriów uczestniczące w procesie apoptozy. Post. Biochem. 51: 447-458.

BORNER C. 2003. The Bcl-2 protein family: sensors and checkpoints for life-ordeath decisions. Mol. Immunol. 39: 615-647.

Breckenridge, D.G., Germain, M., Mathai, J.P., Nguyen, M., Shore, G.C. 2003.

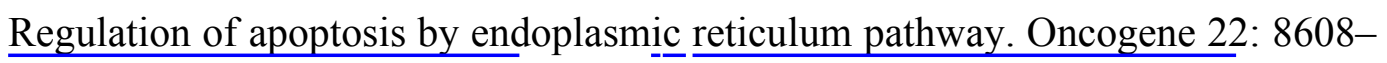
8618.

Brustovetsky, T., Li, T., YANG, Y., Zhang, J.T., Antonsson, B., Brustovetsky, N. 2010. Bax insertion, oligomerization, and outer membrane permeabilization in brain mitochondria: Role of permeability transition and SH-redox regulation. Biochim. Biphys. Acta 1797: 1795-1806.

CaO, X., Deng, X., MAY, W.S. 2003. Cleavage of Bax to p18 Bax accelerates stress-induced apoptosis, and a cathepsin-like protease may rapidly degrade p18 Bax. Blood. 102: 2605-2614. 
Cartron, P.F., Gallenne, T., Bugras, G., Gautier., Manero, F., Vuso, P., Meflah, K., Vallette, F.M., Juin, P. 2004. The first $\alpha$-helix of Bax plays a necessary role in its ligand-induced activation by the BH3-only proteins Bid and Puma. Mol. Cell. 16: 807-818.

Cartron, P.F., Oliver, L., Martin, S., Moreau, C., LeCabellec, M.T., Jezequel, P., Meflah, K., Vallette, F.M. 2002. The expression of a new variant of the pro-apoptotic molecule Bax, Bax psi, is correlated with an increased survival of glioblastoma multiforme patients. Hum. Mol. Genet. 11: 675-687.

Castle, V.P., Heidelberger, K.P., Bromberg, J., Ou, X., Dole, M., Nuñez, G. 1993. Expression of the apoptosis-suppressing protein Bcl-2 in neuroblastoma is associated with unfavorable histology and N-myc amplification. Am. J. Pathol. 143: 1543-1550.

Chipuk, J.E., Bouchier-Hayes, L., Green, D.R. 2006. Mitochondrial outer. membrane permeabilization during apoptosis: the innocent bystander scenario. Cell. Death Differ. 13: 1396-1402.

Chipuk, J.E., Green, D. 2004. Cytoplasmic p53: bax and forward. Cell Cycle. 3: 429-431.

ChIPUK, J.E., GrEen, D. 2008. How do Bcl-2 proteins induce mitochondria outer membrane permeabilization? Trends Cell. Biol. 18: 157-164

Christenson, E., Merlin, S., SAito, M., Schlesinger, P. 2008. Cholesterol effects on Bax pore activation. J. Mol. Biol. 381: 1168-1183.

Codogno, P., MeiJer, A.J. 2006. Atg: more than autophagy factor. Nat. Cell. Biol. 8: 1045-1047.

Cornblau, S.M., Thall, P.F., Estrov, Z., Walterscheid, M., Patel, S., Theriault, A., Keating, M.J., Kantarjian, H., Estey, E., AndreefF, M. 1999. The prognostic impact of $\mathrm{Bc} 12$ protein expression in acute myelogenous leukemia varies with cytogenetics. Clin. Cancer. Res. 5: 1758-1766.

CORY, S., HuANG, D.C., ADAMS, J.M. 2003. The Bcl-2 family: roles in cell survival and oncogenesis. Oncogene 22: 8590-8607. 
Cuddeback, S.M., Yamaguchi, H., Komatsu, K., Miyashita, T., Yamada, M., WU, C., SingH, S., WANG, H.G. 2001. Molecular cloning and characterization of Bif-1. A novel Src homology 3 domain-containing protein that associates with Bax. J. Biol. Chem. 276: 20559-20565.

Day, C.L., Smits, C., Fan, F.C., Lee, E.F., Fairlie, W.D., Hinds, M.G. 2008. Structure of the $\mathrm{BH} 3$ domains from the p53-inducible $\mathrm{BH} 3$-only proteins Noxa and Puma in complex with Mcl-1. J. Mol. Biol. 380: 958-971.

Desagher, S., Osen-Sand, A., Nichols, A., Eskes, R., Montessiut, S., LauPer, S., Maundrell, K., Antonsson, B., Martinou, J.C. 1999. Bid-induced conformational change of Bax is responsible for mitochondrial cytochrome c release during apoptosis. J. Cell Biol. 144: 891-901.

Droin, N. M., GreEN, D. R. 2004. Role of Bcl-2 family members in immunity and disease. Biochim. Biophys. Acta. 1644: 179-188.

Ewings, K.E., Hadfield-Moorhouse, K., Wiggins, C.M., Wickenden, J.A., Balmanno, K., Gilley, R., Degenhardt, K., White, E., Cook, S.J. 2007. ERK1/2-dependent phosphorylation of BimeL promotes its rapid dissociation from Mcl-1 and Bcl-XL. EMBO J. 26: 2856-2867.

FALKE, D., Fisher, M., YE, D., JULIANO, R.L. 2003. Design of artificial transcription factors to selectively regulate the pro-apoptotic bax gene. Nucleic Acids Res. 31(3): e10.

Ferreira, C.G., EpPing, M., KruYt, F.A.E., Giaccone, G. 2002. Apoptosis: target of cancer therapy. Clin. Cancer Res. 8: 2024-2034.

Frey, V., Viaud, J., Subra, G., Cauquil, N., Guichou, J.F., Casara, P., Grassy, G., ChavanieU, A. 2008. Structure-activity relationships of Bak derived peptides: Affinity and specificity modulations by amino acid replacement. Eur. J. Med. Chem. 43: 966-972.

GAO, G., DOU, Q.P. 2000. N-terminal cleavage of Bax by calpain generates a potent proapoptotic $18 \mathrm{kDa}$ fragment that promotes bcl-2-independent cytochrome c release and apoptotic cell death. J. Cell. Biochem. 80: 53-72.

George, N.M., TARgy, N., Evans, J.J., Zhang, L., LuO, X. 2010. Bax contains two functional mitochondrial targeting sequences and translocates to mitochondria in 
a conformational change- and homo-oligomerization-driven process. J. Biol. Chem. 285: 1384-1392.

Gotoh, T., Terada, K., Oyadomari, S., Mori, M. 2004. Hsp70-DnaJ chaperone pair prevents nitric oxide- and CHOP-induced apoptosis by inhibiting translocation of Bax to mitochondria. Cell. Death. Differ. 11: 390-402.

GreIJER, A.E., VAN DER WALL, E. 2004. The role of hypoxia inducible factor 1 (HIF-1) in hypoxia induced apoptosis. J. Clin. Pathol. 57: 1009-1014.

Griffiths, G. J., Corfe, B.M., Savory, P., Leech, S., Esposti, M.D., Hickman, J.A., DivE, C. 2001. Cellular damage signals promote sequential changes at the $\mathrm{N}$-terminus and $\mathrm{BH}-1$ domain of the pro-apoptotic protein Bak. Oncogene 20: 7668-7676.

Guo, B., GodzIK, A., ReED, J.C. 2001. Bcl-G, a novel pro-apoptotic member of the Bcl-2 family. J. Biol. Chem. 276: 2780-2785.

Gurudutta, G.U., Verma, Y.K., Singh, V.K., Gupta, P., Raj, H.G., Sharma, R.K., CHANDRA, R. 2005. Structural conservation of residues in BH1 and BH2 domains of Bcl-2 family proteins. FEBS Lett. 579: 3503-3507.

Hanson, C.J., Bootman, M.D., Distelhorst, C.W., Maraldi, T., Roderick, H.L. 2008. The cellular concentration of Bcl-2 determinates its pro- or anti-apoptotic effect. Cell. Calcium 44: 243-258.

HAYAShI, T., FAustMAn, D.L. 2003. Role of defective apoptosis in type 1 diabetes and other autoimmune diseases. Rec. Prog. Horm. Res. 58: 131-153.

Hengartner, M.O. 2000. The biochemistry of apoptosis. Nature 407: 770-776.

Hetz, C., GLimCher, L. 2008. The daily job of night killers: alternative roles of the Bcl-2 family in organelle physiology. Trends. Cell. Biol. 18: 38-44.

Hossini, A. M., EBerle, J. 2008. Apoptosis induction by Bcl-2 proteins independent of the BH3 domain. Biochem. Pharmacol. 76: 1612-1619.

HÜCKELHOVEN, R. 2004. Bax inhibitor-1, an ancient cell death suppressor in animals and plants with prokaryotic relatives. Apoptosis 9: 299-307.

Jansen, B., Schlagbauer-Wadl, H., Brown, B.D., Bryan, B.D., van Elsas, A., Müller, M., Wolff, K., Eichler, H.G., Pehamberger, H. 1998. Bcl-2 antisense therapy chemosensitizes human melanoma in SCID mice. Nat. Med. 4: 232-234. 
Jin, K.L., Graham S.H., Mao, X.O., He, X., Nagayama, T., Simon, R.P., GreEnBERG, D.A. 2001. Bax kappa, a novel Bax splice variant from ischemic rat brain lacking an ART domain, promotes neuronal cell death. J. Neurochem. 77: $1508-1519$.

KARST, A.M., LI, G. 2007. BH3-only proteins in tumorigenesis and malignant melanoma. Cell. Mol. Life Sci. 64: 318-330.

Kataoka, T., Holler, N., Micheau, O., Martinon, F., Tinel, A., Hofmann, K., TSCHOPP, J. 2001. Bcl-rambo, a novel Bcl-2 homologue that induces apoptosis via its unique C-terminal extension. J. Biol. Chem. 276: 19548-19554.

Ke, N., GodzIK, A., ReED, J.C. 2001. Bcl-B, a novel Bcl-2 family member that differentially binds and regulates Bax and Bak. J. Biol. Chem. 276: 1248112484.

Khor, L.Y., Moughan, J., Al-Saleem, T., Hammond, E.H., Venkatesan, V., Rosenthal, S.A., Ritter, MA., SAndler, H.M., Hanks, G.E., Shipley, W.U., PollACK, A. 2007. Bcl-2 and Bax expression predict prostate cancer outcome in men treated with androgen deprivation and radiotherapy on radiation therapy oncology group protocol 92-02. Clin. Cancer Res. 13: 3585-3590.

KILIAŃSKA, Z.M. 2002. Apoptoza organizmów zwierzęcych. In: L. KŁYSZEJKOSTEFANOWICZ (ed.) Cytobiochemia. Biochemia niektórych struktur komórkowych. Wydawnictwo Naukowe PWN, Warszawa, pp. 772-814.

Kobayashi, T., Sawa, H., Morikawa, J., Zhang, W., ShikU, H. 2000. Bax induction activates apoptotic cascade via mitochondrial cytochrome $c$ release and Bax overexpression enhances apoptosis induced by chemotherapeutic agents in DLD-1 colon cancer cells. Jpn. J. Cancer Res. 91: 1264-1268.

Kobylinska, A., Bednarek, J., Blonski, J.Z., Hanausek, M., Walaszek, Z., RoBAK, T., KILIANSKA, Z.M., 2006. In vitro sensitivity of B-cell chronic lymphocytic leukemia to cladribine and its combinations with mafosfamide and/or mitoxantrone. Oncol. Rep. 16: 1389-1395.

Kolluri, S.K., Zhu, X., Zhou, X., Lin, B., Chen, Y., Sun, K., Tian, X., Town, J., CaO, X., Lin, F., Zhai, D., Kitada, S., Luciano, F., Donnell, E., CaO, Y., He, F., Lin, J., Reed, J.C., SATterthwait, A.C., Zhang, X.K. 2008. A short Nur77- 
derived peptide converts Bcl-2 from a protector to a killer. Cancer Cell.14: 285298.

Konopleva, M., Tari, A.M., Estrov, Z., Harris, D., Xie, Z., Zhao, S., LópezBerestein, G., ANDreEFF, M. 2000. Liposomal Bcl-2 antisense oligonucleotides enhance proliferation, sensitize acute myeloid leukemia to cytosine-arabinoside, and induce apoptosis independent of other antiapoptotic proteins. Blood 95: 3929-3938.

Krajewsi, S., Krajewska, M., Ellerby, L.M., Welsh, K., Xie, Z., DeverauX, Q.L., Salvesen, G.S., Bredesen, D.E., Rosenthal, R.E., Fiskum, G., Reed, J.C. 1999. Release of caspase-9 from mitochondria during neuronal apoptosis and cerebral ischemia. Proc. Natl. Acad. Sci. U.S.A. 96: 5752-5757.

Kumarswamy, R., Chandna, S. 2009. Putative partners in Bax mediated cytochrome-c release: ANT, CypD, VDAC or none of them? Mitochondrion 9: $1-8$.

LeBer, B., Lin, J., ANDREWs, D.W. 2007. Embedded together: the life and death consequences of interaction of the Bcl-2 family with membranes. Apoptosis. 12: 897-911.

Lee, R.M., Chen, J., Matthews, C.P., McDougall, J.K., Neiman, P.E. 2001. Characterization of NR13-related human cell death regulator, Boo/Diva, in normal and cancer tissues. Biochim. Biophys. Acta 1520: 187-194.

Li, X., Marani, M., Yu, J., Nan, B., Roth, J.A., Kagawa, S., Fang, B., Denner, L., MARCELLI, M. 2001. Adenovirus-mediated Bax overexpression for the induction of therapeutic apoptosis in prostate cancer. Cancer Res. 61: 186-191.

Lin, B., Kolluri, S.K., Lin, F., LiU, W., Han, Y.H., CaO, X., Dawson, M.I., ReED, J.C., ZHANG, X.K. 2004. Conversion of Bcl-2 from protector to killer by interaction with nuclear orphan receptor Nur77/TR3. Cell 116: 527-540.

Lowe, S.W., CEPero, E., Evan, G. 2004. Intrinsic tumour suppression. Nature 432: 307-315.

Luciano, F., Krajewska, M., Ortiz-Rubio, P., Krajewski, S., Zhai, D., Faustin, B., Bruey, J.M., Bailly-Maitre, B., Lichtenstein, A., Kolluri, S.K., Satterthwait, A.C., Zhang, X.K., ReED, J.C. 2007. Nur77 converts phenotype 
of Bcl-B, an antiapoptotic protein expressed in plasma cells and myeloma. Blood. 109: 3849-3855.

Lucken-Ardjomande, S., Martinou, J.C. 2005. Regulation of Bcl-2 proteins and of the permeability of the outer mitochondrial membrane, Regulation of Bcl-2 proteins and of the permeability of the outer mitochondrial membrane. C. R. Biol. 328: 616-631.

Luo, X., Budihardjo, J., Zou, H., Slaughter, C., Wang, X. 1998. Bid, an Bcl-2 interacting protein, mediates cytochrome $\mathrm{c}$ release from mitochondria in response to activation of cell surface death receptors. Cell 94: 481-490.

Majewski, N., Nogueira, V., Bhaskar, P., Coy, P.E., Skeen, J.E., Gottlob, K., Chandel, N.S., Thompson, C.B., Robey, R.B., Hay. N. 2004. Hexokinasemitochondria interaction mediated by Akt is required to inhibit apoptosis in the presence or absence of Bax and Bak. Mol. Cell. 16: 819-830.

Meir, O., Dvash, E., Werman, A., Rubinstein, M. 2010. C/EBP-beta regulates endoplasmic reticulum stress-triggered cell death in mouse human models. PLOS One 5: e9516.

Ming, L., WANG, P., BANK, A., ZHANG, L. 2006. PUMA dissociates Bax and Bcl-xL to induce apoptosis in colon cancer cells. J. Biol. Chem. 281: 16034-16042.

Moldoveanu, T., Liu, Q., Tocilj, A., Watson, M., Shore, G., Gehring, K. 2006. The X-ray structure of Bak homodimer reveals an inhibitory zinc binding site. Mol. Cell. 24: 677-688.

Ndozangue-Touriguine, O., Hamelin, J., BréArd, J. 2008. Cytoskeleton and apoptosis. Biochem. Pharmacol. 76: 11-18.

OltVAI, Z., KorSMEYeR, S. 1993. Bcl-2 heterodimrizes in vivo with conserved homolog, Bax, that accelerates programmed cell death. Cell 74: 609-619.

Ouyang, H., Furukawa, T., ABe, T., Kato, Y., HoriI, A. 1998. The BAX gene, the promoter of apoptosis, is mutated in genetically unstable cancers of the colorectum, stomach, and endometrium. Clin. Cancer. Res. 4: 1071-1074.

PePPeR, C., Hoy, T., Bentley, D.P. 1997. Bcl-2/Bax ratios in chronic lymphocytic leukemia and their correlation with in vitro apoptosis and clinical resistance. $\mathrm{Br}$. J. Cancer 76: 935-958. 
Perez, G.I., Knudson, C.M., Leykin, L., Korsmeyer, S.J., Tilly, J.L. 1997. Apoptosis-associated signaling pathways are required for chemotherapy-mediated female germ cell destruction. Nat. Med. 3: 1228-1332.

Petros, A.M., OlejniCZaK, E.T., FesiK, S.W. 2004. Structural biology of the Bcl-2 family of proteins. Biochim. Biophys. Acta 1644: 83-94.

Pirocanac, E.C., Nassirpour, R., Yang, M., Wang, J., Nardin, S.R., Gu, J., Fang, B., Moossa, A.R., Hoffman, R.M., Bouvet, M. 2002. Bax-induction gene therapy of pancreatic cancer. J. Surg. Res. 106: 346-351.

Rampino, N., Yamamoto, H., Ionov, Y., Li., Y., Sawai., H., Reed, J.C., Perucho, M. 1997. Somatic frameshift mutations in the BAX gene in colon cancers of the microsatellite mutator phenotype. Science 275: 967-969.

REED, J.C. 1999. Dysregulation of apoptosis in cancer. J. Clin. Oncol. 17: 29412953.

REED, J.C. 2008. Bcl-2 family proteins and hematologic malignancies: history and future prospects. Blood. 111: 3322-3330.

Rodolfo C., Piacentini M. 2002. Does cytoskeleton 'Akt' in apoptosis? Cell. Death Differ. 9: 477-478.

Rogalińska, M., BŁoński, J.Z., Komina, O., GóRAlski, P., ŻoŁnierczYK, J.D., Piekarski, H., Robak, T., KiliańsKa, Z.M., Wesierska-GadeK, J. 2010. Rroscovitine (Seliciclib) affects CLL cells more strongly than combinations of fludarabine or cladribine with cyclophosphamide: Inhibition of CDK7 sensitizes leukemic cells to caspase-dependent apoptosis. J. Cell. Biochem. 76: 11-18.

Savaraj, N., You, M., Wu, C., WangPaichitr, M., Kuo, M.T., Feun, L.G. 2010. Arginine deprivation, autophagy, apoptosis (AAA) for the treatment of melanoma. Curr. Mol. Med. 10: 405-412.

Schinzel, A., KAUfMAnN, T., Borner, C. 2004a. Bcl-2 family members: integrators of survival and death signals in physiology and pathology [corrected]. Biochim. Biophys. Acta. 1644: 95-105.

Schinzel, A., Kaufmann ,T., Schuler, M., Martinalbo, J., GrubB, D., Borner, C. 2004b. Conformational control of Bax localization and apoptotic activity by Pro168. J. Cell. Biol. 164: 1021-1032. 
Schlesinger, P.H., Saito, M. 2006. The Bax pore in liposomes. Biophysics. Cell. Death Differ.13: 1403-1408.

SCHRÖDER, M. 2008. Endoplasmic reticulum stress responses. Cell. Mol. Life Sci. 65: 862-894.

SEO, E., KIM, S., JHO, E.H. 2009. Induction of cancer cell-specific death via MMP2 promoter-dependent Bax expression. B. M. B. Rep. 42: 217-222.

Shan, Y.X., Liu, T.J., Su, H.F., Samsamshariat, A., Mestril, R., Wang, P.H. 2003. Hsp10 and Hsp60 modulate Bcl-2 family and mitochondria apoptosis signaling induced by doxorubicin in cardiac muscle cells. J. Mol. Cell. Cardiol. 35: $1135-1143$.

Sharpe, J.C., Arnoult, D., Youle, R.J. 2004. Control of mitochondrial permeability by Bcl-2 family members. Biochem. Biophys. Acta 1644: 107-113.

Skommer, J., Wlodkowic, D., Deptala, A. 2007. Larger than life: mitochondria and the Bcl-2 family. Leuk. Res. 31: 277-286.

SuzuKi, M., Youle, R.J., TJANDRA, N. 2000. Structure of Bax: coregulation of dimer formation and intracellular localization. Cell 103: 645-654.

Takahashi, Y., Karbowski, M., Yamaguchi, H., Kazi, A., Wu, J., Sebti, S.M., Youle, R.J., WAng, H.G. 2005. Loss of Bif-1 suppresses Bax/Bak conformational change and mitochondria apoptosis. Mol. Cell. Biol. 25: 93699382.

Terrones, O., Antonsson, B., Yamaguchi, H., Wang, H.G., Liu, J., Lee, R.M., Herrmann, A., BasañEz, G. 2004. Lipidic pore formation by the concerted action of proapoptotic Bax and tBid. J. Biol. Chem. 279: 30081-30091.

Wagener, C., Bargou, C., Daniel, P.T., Bommert, K., Mapara, M.Y., Royer, H.D., DÖRKEN, B. 1996. Induction of the death-promoting gene bax- $\alpha$ sensitizes cultured breast-cancer cells to drug-induced apoptosis. Int. J. Cancer 67: 138141.

WARR, M.R., SHORE, G.C. 2008. Small-molecule Bcl-2 antagonists as targeted therapy in oncology. Curr. Oncol. 15: 256-261. 
Wei, M.C., Lindsten, T., Mootha V.K, Weiler, S., Gross, A., AshiYa, M., Thompson, C.B., KorsmeYer, S.J., 2000. tBid, a membrane-targeted death ligand, oligomerizes BAK to release cytochrome c. Genes Dev. 14: 2060-2071.

WyLLIE, A.H. 2010. "Where, o death, is thy sting?" A brief review of apoptosis biology. Mol. Neurobiol. 42: 4-10.

XU, Q., REED, J.C., 1998, Bax inhibitor-1, a mammalian apoptosis suppressor identified by functional screening in yeast. Mol. Cell. 1: 337-346.

YAN, N., SHI, Y. 2003. Histone H1.2 as a trigger for apoptosis. Nat. Struct. Biol. 10: 983-985.

Yedavalli, V.S., Shih, H.M., Chiang, Y.P., Lu, C.Y., Chang, L.Y., Chen, M.Y., Chuang, C.Y., Dayton, A.I., Jeang, K.T., Huang, L.M. 2005. Human immunodeficiency virus type 1 Vpr interacts with antiapoptotic mitochondrial protein HAX1, J. Virol. 79: 13735-13746.

Yousefi, S., Perozzo R., Schmid, I., Ziemiecki, A., Schaffner, T., Scapozza, L., BRUNNER, T., Simon, H.U. 2006. Calpain-mediated cleavage of Atg5 switches autophagy to apoptosis. Nat. Cell. Biol. 8: 1124-1132.

Zamzami, N., Hamel, E., Maisse, C., Brenner, C., Muñoz-Pinedo, C., BalzacQ, A.S., Costantini, P., Vieira, H., Loeffler, M., Molle, G., Kroemer, G. 2000. Bid acts_on the permeability transition_pore complex to induce apoptosis. Oncogene 19: 6342-6350.

Zhai, D., Luciano, F., Zhu, X., Guo, B., Satterthwait, A.C., Reed, J.C. 2005. Humanin binds and nullifies Bid activity by blocking its activation of Bax and Bak. J. Biol. Chem. 280: 15815-15824.

ŻoŁnierczYK, J.D., BŁoŃSKI, J.Z., RoBAK, T., KILIAŃSKA, Z.M., WeSIERSKAGADEK, J. 2009. Roscovitine triggers apoptosis in B-cell chronic lymphocytic leukemia cells with similar efficiency as combinations of conventional purine analogs with cyclophosphamide. Ann. N.Y. Acad. Sci. 1171: 124-131. 